\title{
Financial Risk Analysis and Regulatory Suggestions for Shadow Banking
}

\author{
Yilu Li \\ Faculty of Economic Law, Shanghai University of Political Science and Law, Shanghai, 201701, China \\ Email:956291739@qq.com
}

\begin{abstract}
With the rapid expansion of shadow banking in China, its effect of risk prevention and control is initially effective, but related financial risks are still accumulating. The People's Bank of China mentioned in its 2019 China Financial Stability Report that "properly defusing the risks of shadow banking" would help push forward the fight against major financial risks. Starting from the international origin of shadow banking, this paper deeply analyzes the shadow banking system of China, and draws lessons from the international supervision suggestions, starting from the financial risks caused by shadow banking in China, strengthens the important supervision policies of shadow banking both at home and abroad, and further discusses how to strengthen the penetration regulation of shadow banking.
\end{abstract}

Keywords: shadow banking, financial risk, regulatory suggestions

\section{ORIGIN AND DEVELOPMENT OF SHADOW BANKING FROM AN INTERNATIONAL PERSPECTIVE}

Internationally, shadow banking was originated in the United States in the 1970s. In 2007, due to the outbreak of the financial crisis in the United States1, "shadow banking" began to receive international attention, so that the shadow banking system hidden under the "shadow" exposed and triggering hot discussions on its supervision at home and abroad. It has been more than a decade now. The rapid development of shadow banking is in the early 21 st century, affected by September 11 Attacks, the U.S. economy is in a depression period, in order to improve the economic depression at that time and enable the economy to recover, the government adopted successive interest rate cuts, leading to the excess liquidity of global currency. In this context, shadow banking was widely popular with its features of low financing cost, strong liquidity and convenient transaction. By March 2008, the liabilities of "shadow banking" in the United States had exceeded 21 trillion US dollars at one time, which was even larger than the credit scale of commercial banks at that time, and a large number of financial institutions and financial innovation tools came into being2. With the rapid development of global information network and the promotion of economic globalization, the definition of shadow banking in the international industry is developing towards diversification.

After the global financial crisis, the collapse of Lehman Brothers Holdings and the run on the Reserve Primary Fund money market fund 3 drew attention to the fact that shadow banking had a monetary function, and the Federal Reserve at the time proposed the concept of "shadow banking" for such non-bank institutions, which was firstly proposed by McCulley, the executive president of Pacific Investment Management Company and then widely adopted, it is also known as "The Parallel Banking System". In a great deal of research on shadow banking, the International Monetary Fund (IMF) has summarized the international academic standards for defining shadow banking: Firstly, it generally refers to financial intermediaries that are separate from the regulatory system and correspond to banks. Secondly, it refers to innovative financial instruments and financial activities. Thirdly, it refers to securitization market or financial derivatives. Despite the convergence of its definitions, given the disparate economic development and financial structure of countries, based on the uniqueness of "shadow banking" in each country, the Financial Stability Board (FSB) concluded in its 2013 Global Shadow Banking 
Monitoring Report that there may not be an international standard for specific types of shadow banking, depending on the particular nature of the financial system and regulatory system in different economies. In China, however, the composition of shadow banking is quite different from that of developed market countries4.

\section{INTRODUCTION TO CHINA'S SHADOW BANKING SYSTEM}

\subsection{Emergence of shadow banking in China}

China's shadow banking, dominated by banks, is essentially the shadow of disguised lending and banking, and is the product of intertwined symbiosis of financial institution innovation, profit seeking and regulatory evasion. The funds of shadow banking in China mainly come from the banking system. Although there are a variety of management institutions among intermediate managers, the business of the shadow banking system in China as a whole still depends on the banking system. And with the development of the banking system in China, the shadow banking also has its complicated and changeable economic background, which is the development of multi-forces. Firstly, the demand of the market and the increasing demand of the market enable the shadow banking to develop rapidly. Secondly, the rapid transformation of financial network technology provides necessary technical support to shadow banking. With the rise of internet finance, more and more new financial products come into being, and shadow banking products can appear in more hidden and complicated forms.

\subsection{Different attitudes of theorists to the shadow banking}

As a matter of fact, there is no final conclusion on the quality of shadow banking at home and abroad, and the attitude of theorists to shadow banking is different. Some scholars believe that the rapid development of shadow banking in China over the past few years has played a very positive role in Chinese economy. For example, Li Yang, vice-president of the Chinese Academy of Social Sciences, has been a strong supporter of shadow banking on many occasions. He once said that: "The shadow banking system is produced in response to the diversified demands of financiers and investors and developed on the basis of modern information industry. In this sense, they represent the future direction of the financial industry." 4 "Society needs shadow banking." Others argue that China's corporate debt levels are already high and that "shadow banking" is outside of the regulatory system, and is far less transparent and normative than commercial banks, causing financial risks to accumulate and even greater crises. On December 13, 2018, for example, Yi Gang, president of the People's Bank of China, said in a public speech that: "Regulated shadow banking is a necessary complement to financial markets." 5 However, policymakers' view of shadow banking remains more negative than positive.

\subsection{Analysis of the Similarities and Differences between Shadow Banking in China and America}

\subsubsection{Differences}

Firstly, the substance of the two is different. The essence of shadow banking in America is that non-depository institutions function as banks outside of regulation, while the essence of China's shadow banking is the shadow of banks. 6 The main source of funds of shadow banking in America is capital fund, which is the off-balance-sheet operation of complete capital flow under the mode of "initiation-distribution", and the core is asset securitization, which coexists with the traditional commercial banking system and forms a competitive relationship within the industry. In essence, China's shadow banking is dominated by banks, and is a shadow of disguised lending and banking. Unlike the highly securitisation in America, China's shadow banking does not form a complete chain of trust between institutions and businesses, which is, as a shadow of banks, it forms a complementary relationship with banks.

Secondly, the reasons for their formation are different. An important reason for the appearance of shadow banking in America is the blind optimism of the financial regulatory authorities. Before the financial crisis, the shadow banking system in America was already larger than the traditional banks, and for a number of reasons, the shadow banking system in America expanded rapidly because of lax regulatory oversight of the regulatory authorities to shadow banking. Different from the financial environment in America, the appearance of China's shadow banking system is the result of the tightening of macro-financial policy, which is caused by the imperfect financial environment in China at that time, and solves the problem of traditional credit. 7

\subsubsection{Similarities}

After the financial crisis, countries have launched a series of reform measures to strengthen supervision of shadow banking, contrasting the common features of 
China and America in three aspects: Firstly, integrate shadow banking into the overall financial regulatory system and provide different regulatory schemes according to the characteristics of different products in the system, especially strengthening effective supervision of the securities and repo markets. Secondly, further improve the supervision of traditional commercial banks, such as America's "Volcker Rules" forbid Banks from holding or investing in over-the-counter derivatives unless they are in exceptional circumstances. Thirdly, in order to prevent moral hazard, banks need to establish the disposal scheme of the crisis caused by the issuer's fault in the process of asset securitization, so as to ensure that the loss can be controlled within a certain range in time after the outbreak of the crisis.

\section{FINANCIAL RISKS CAUSED BY SHADOW BANKING IN CHINA}

\subsection{Hidden financial risks of shadow banking}

Firstly, there are some liquidity risks in shadow banking in China. Banks meet the capital requirements of long-term assets by combining short-term wealth management products in the capital pool. There are insurmountable deadlines and mismatches. Secondly, there are market risks and credit risks in shadow banking. On the one hand, due to the influence of the market and product issuers, risk rating agencies tend to relax their requirements on rating, which leads to the extremely high risk of some high-lever financial products, and the market is difficult to control the degree of harm. On the other hand, due to the inequality and asymmetry of market information, borrowers are easy to generate moral hazard, and lenders are more likely to make adverse selection in case of market crisis.

\subsection{It is easy for shadow banking to evade supervision}

China's shadow banking has a regulatory gap or inadequate regulatory. Through the above analysis of shadow banking, it is not difficult to conclude that as the capital market and money market, the two financial transactions, shadow banking is separated from the middle of the two.8 This shows that shadow banking has different characteristics, such as different forms, specific forms and types of transactions, which tend to be capital transactions or currency transactions or both. Thus, neither the emphasis on disclosure of regulatory information in capital transactions nor the protection of strict regulation in currency transactions can correspond to the diversification shown by shadow banking.

\section{EXISTING GOVERNANCE AND INTERNATIONAL EXPERIENCE OF SHADOW BANKING IN CHINA}

\subsection{China's governance measures}

At present, China's governance measures are mainly embodied in the following two aspects: Firstly, bring China's shadow banking system into the scope of financial supervision, such as in the supervision of commercial banks, introduced Interim Measures for the Administration of Personal Finance Services of Commercial Banks, Management Measures for the Sale of Financial Products by Commercial Banks; In the supervision of trust companies, introduced Measures on Net Capital Management of Trust Companies; In the supervision of enterprises or companies, introduced Measures for the Administration of Financial Companies of Enterprise Groups, Measures for the Implementation of Administrative Licensing Matters of Non-Bank Financial Institutions and Measures for the Pilot Administration of Consumer Financial Companies. Secondly, clear responsibilities at the regulators, such as the creation of Financial Stability Board at the 2017 financial work conference. Different from the State Council's Approval on Agreeing to the Establishment of an Inter-ministerial Joint Meeting on Financial Supervision and Coordination in 2013, the joint meeting established is just a communication institution led by the Central bank, which has no power of administrative supervision and punishment, while the Financial Stability Board is subordinate to the State Council and has substantive supervision power.

\subsection{Experience in international governance}

After the financial crisis, Europe and the United States began to consider the shadow banking system into the regulation. From the perspective of the U.K., the Financial Services Authority (FSA) issued a report in 20099 calling for stronger regulation of shadow banking such as hedge funds. Major bills and directives include Turner Review, Prudential Systems for Trading Behavior and Reform of the Over-the-Counter Market for Derivatives; From the perspective of the U.S., the U.S. government also announced Comprehensive Reform of Financial System in March 2009 to tighten regulation of shadow banking such as hedge funds. Require hedge funds and other private equity funds above a certain size to register with the U.S. Securities and Exchange Commission (SEC) and establish a comprehensive regulatory, protection and disclosure framework for over-the-counter derivatives markets such as CDS; From international perspective, the international financial legal system reform led by FSB in shadow banking supervision has reached consensus in 
the international community. The FSB studies the definition and scope of shadow banking, monitoring methods, regulatory objectives and measures in determining the international standards for shadow banking regulation.

\section{SUGGESTIONS ON MEASURES TO STRENGTHEN THE SUPERVISION OF SHADOW BANKING}

\subsection{Targeted guidance according to the different characteristics of shadow banking}

Due to the diversity (multi-subjects, multi-channels and multi-forms) of shadow banking in China, it is necessary to strengthen the coordination of separated supervision and strengthen the penetrating supervision of shadow banking products. In China's current separated supervision environment, due to the high cost of regulatory departments' input in regulatory compliance, regulatory standards have different characteristics in various industries. The supervision of shadow banking is faced with the main problem that the regulatory arbitrage space is too large. Therefore, under the unified supervision principle, similar businesses shall be supervised to the same standard, regulatory coordination shall be enhanced, and efforts shall be made to reduce the regulatory gap and eliminate the regulatory arbitrage space. For example, securities companies and fund companies have relatively loose regulatory requirements for asset management business, while banking system and trust financial institutions have relatively strict regulatory requirements for asset management business, they shall be placed under the same strict standard; the trust law that trust companies rely on is different from the principal-agent relationship that general asset management business relies on, in terms of supervision, it shall be administered according to the class and shall pay attention to the differences in law.

\subsection{Clarify the scope of supervision by the supervisory agencies}

In order to adapt to the current situation of financial supervision in China, it shall be one of the main tasks to allocate and confirm the supervisory responsibilities of all agencies and departments under the condition of separated supervision, so as to gradually form an efficient and accurate regulatory cooperation system. From the macro point of view, strengthen coordination among different regulatory agencies, minimize the problems of regulatory gap and regulatory duplication, promote the sharing of resources and information among different institutions, and make full use of the joint meeting system of financial supervision. From the micro point of view, an independent and professional shadow banking business regulatory agency is formed among each regulatory agency, so that various types of shadow banking have special regulatory research and regulation methods, and constantly strengthen the level of innovative risk management of shadow banking business and derivative products.

\subsection{Improve transparency and improve the information disclosure system}

At present, China's financial sector has not formed a sound and mature information disclosure system, and the importance of information disclosure has not attracted the attention of the existing regulatory authorities, the transparency of shadow banking has not been standardized. Asymmetric information may lead to the occurrence of financial fraud or unfair competition and other irregularities, thus the transparency of shadow banking shall be increased. Firstly, it is necessary to construct a platform for information disclosure in a timely manner and to collect information in a unified way so as to keep market data up-to-date with statistics and analysis; Secondly, it is necessary to publish non-standard over-the-counter trading cases in a timely manner so as to further restrict the operation of highly leveraged financial products in compliance with trading standards, and to clearly define the scope of shadow banking, so as to avoid the systemic risk caused by non-compliance transaction; Thirdly, it is necessary to further improve the business level of relevant supervisors and set up high-quality supervision team, at the same time, improve the diversity and accuracy of assessment standards and measurement methods at the technical level.

\section{CONCLUSION}

Shadow banking is the product of global economic development and financial diversification. Although there is no clear definition and demarcation of shadow banking, its impact on the economy is undeniable. China's shadow banking development is a double-edged sword, and shall be treated rationally and comprehensively, that is, both to recognize its role in promoting China's economy, and absolutely cannot ignore its huge regulatory pressure on China's financial markets. Therefore, while improving various systems, we must also provide targeted guidance in accordance with the different characteristics of shadow banking, and give full play to the positive role of transparent supervision, under the condition of implementing separate supervision, clarify the supervision scope of each supervisory agency, improve the information disclosure system to further promote the stable and orderly development of China's financial market.

\section{REFERENCES}

[1] Ba Shusong, Regulatory Trends of Shadow Banking in China, Financial Book Club, 2017 
[2] Liu Guixiang, Study of China's Shadow Banking Regulation in the Post-Financial Crisis Era, Jilin University of Finance and Economics, 2014

[3] Sun Guofeng, Definition of China's Shadow Banking and Its Scale Estimation, 2018 (4)

[4] Qu Zhaoguang, Micro Operating Mechanism, Macro Impact and Research Methods of Shadow Banking System, 2019 (10)

[5] Li Li, Risk Causes and Regulatory Countermeasures of "Chinese" Shadow Banking, 2014 (06)

[6] Wen Hanmin, Analysis of the Advantages and Disadvantages of "Shadow Banking" and Its Countermeasures, 2014

[7] Li Zhan, Fang Pengfei: Accurate Understanding of Shadow Banking - a Prerequisite for Resolving the Risks of Shadow Banking, 2019 (1)

[8] Li Shaojun, The Causes of Shadow Banking in China form Comparative Study between China and America - One of the Special Series on Financial Stability, 2017 (07)

[9] Pan Jing, Comparative Study of the Chinese and American Shadow Banking Systems, 2013

[10] Zhu Ciyun: Shadow Banking in China: Rise, Nature, Governance and Regulatory Innovation

[11] Ba Shusong, Regulatory Trends of Shadow Banking in China, 2017

[12] Yuan Dasong: Reform of the International Financial Legal System to Strengthen Regulation of Shadow Banking, 2020 